\title{
FORAMEN IN THE SHIELD: FORAMEN THYROIDEUM
}

\author{
Parmanand Agarwal1, Yuvaraj Jayprakash Bhosale ${ }^{2}$
}

${ }^{1}$ Assistant Professor, Department of Anatomy, Government Medical College, Gondia, Maharashtra.

${ }^{2}$ Additional Professor, Department of Anatomy, Seth G.S. Medical College and KEM Hospital, Parel, Mumbai.

\section{ABSTRACT}

\section{BACKGROUND AND OBJECTIVES}

Opening (foramen) existing in one or both plates of the thyroid cartilage, which may or may not contain a neurovascular component is known as foramen thyroideum. The purpose of present study was to look for presence of foramina in thyroid cartilage, to note the position of the foramen, the symmetry and the presence of neurovascular bundle.

\section{METHODS}

After due permission from the ethics committee of the institution, sixty specimens ( 51 males and 9 females) of apparently healthy larynx were obtained from embalmed cadavers. The larynx was procured after meticulous dissection. The specimens were looked for presence of foramina and if present, its position, symmetry, and presence or absence of neurovascular bundle was noted.

\section{RESULTS}

Out of 60 larynges, foramen thyroideum was found in seven (11.6\%) larynges. Of these, $40 \%$ was present on the oblique line and $30 \%$ each to anterior and posterior of oblique line respectively.

\section{INTERPRETATION AND CONCLUSION}

These variant is of high interest for surgeons intervening in the larynx due to potential complications such as bleeding and neural impairment. The oblique line of the thyroid lamina acts as the best topographical landmark to identify any aberrant anatomy related to a thyroid foramen.

\section{KEYWORDS}

Foramen Thyroideum, Larynx, Thyroid Cartilage.

HOW TO CITE THIS ARTICLE: Agarwal P, Bhosale YJ. A foramen in the shield: foramen thyroideum. J. Evolution Med. Dent. Sci. 2016;5(64):4512-4514, DOI: 10.14260/jemds/2016/1030

\section{INTRODUCTION}

Larynx is an air passage, a sphincter and an organ of phonation. Skeletal framework of larynx is formed by series of cartilages viz. unpaired thyroid, cricoid, and epiglottis and paired arytenoid, cuneiform, and corniculate. The larynx is the upper part of the respiratory tract. Its function is to protect the lower respiratory tract so that foreign bodies do not enter the trachea. If a foreign body comes in contact with the mucosa of the larynx, it reflexly gives rise to violent coughing till the foreign body is expelled.(1)

Galen named the four-sided cartilage of larynx as thyroid, which means "a shield shape." The thyroid cartilage is named so because it acts as a shield (protection) for the airway.

Opening (foramen) existing in one or both plates of the thyroid cartilage, which may or may not contain a neurovascular component is known as Foramen Thyroideum (FT). Present study highlights the anatomic features and its clinical implications. The foramen thyroideum is important for two reasons; first, the surgical exposure, and second, the spread of the laryngeal cancer. Knowing the anatomy and the incidence of the foramina is important for preserving the foramina contents.

Financial or Other, Competing Interest: None.

Submission 18-07-2016, Peer Review 30-07-2016,

Acceptance 02-08-2016, Published 09-08-2016.

Corresponding Author:

Dr. Parmanand Agarwal,

Assistant Professor,

Department of Anatomy,

Government Medical College,

Gondia, Maharashtra.

E-mail: parma.agarwal6@gmail.com

DOI: $10.14260 /$ jemds/2016/1030
Also to preserve the laryngeal nerve in the conservative resection of laryngeal, it is required to know this crucial anatomy of thyroid cartilage. Since tumour invasion through the posterosuperior portion of the thyroid ala into extralaryngeal tissues is possible. Foramen thyroideum containing neurovascular elements is a possible pathway of tumour spread.

Embryologically, two hypotheses have been proposed to explain the origin of the FT. The first is the branchial origin; FT is considered to be an incomplete union of the cartilaginous elements of the fourth and sixth pharyngeal arches from which the thyroid lamina is derived. The second is the neurovascular theory; it is associated with chondrification defect of the thyroid lamina caused by the presence of the vessel and/or nerves.(2)

Leon et al reported that the neurovascular origin of the FT could not explain the existence of the $32 \%$ of the embryonic fetal FT without vessels and/or nerves. They suggested another hypothesis, which is a combination of the previous theories that the FT appeared to be a failure in the chondrification of the mesenchymal elements derived from the fourth and sixth pharyngeal arches associated with the presence of the vessels and/or nerves proceeding from the superior laryngeal pedicle.

When not crossed by neurovascular elements, the FT involutes and disappears.(2) There is paucity of knowledge about foramen thyroideum in Indian population, so present study was undertaken to look for presence of foramina in thyroid cartilage (foramen thyroideum) and to note the position, symmetry, and presence of neurovascular bundle of the foramen. 


\section{MATERIALS AND METHOD MATERIALS}

Sixty specimens (51 males and 9 females) of apparently healthy larynx were obtained from embalmed cadavers of a tertiary care teaching institute. All the cadavers were adult ranging between the age group of 18-65 years. The study consisted of meticulous dissection using standard dissection kit. The methodology of this study is based on the observations of morphology. In each cadaver, the larynx was looked for any gross deformity and specimens were selectively included in this study. The study was done only after due permission from the ethics committee of the institution.

\section{METHODS}

The cadavers used in this study were the ones used by the medical students for the dissection purpose. The specimens were obtained only after the students had finished the dissection of face and the triangles of the neck. The larynx specimen was recovered along with tongue, hyoid bone, proximal trachea, pharynx, and proximal part of oesophagus. Then, the epiglottis was separated from tongue. The thyrohyoid membrane was cut to separate the hyoid bone from the thyroid cartilage. From the posterior aspect, the pharynx and oesophagus were removed to expose the intrinsic muscle of larynx. The thyroid cartilage was cleared of soft tissue and looked for presence of any foramen. The finding were recorded in a sheet and analysed.

\section{RESULTS}

\begin{tabular}{|c|c|c|c|}
\hline \multirow{2}{*}{ Gender } & \multicolumn{2}{|c|}{ Unilateral } & \multirow{2}{*}{ Bilateral } \\
\cline { 2 - 3 } & Right & Left & \\
\hline Male & 1 & 2 & 3 \\
\hline Female & 0 & 1 & 0 \\
\hline \multicolumn{2}{|c}{ Table 1: Presence of Foramen Thyroideum } \\
\hline
\end{tabular}

Out of 60 larynges, foramen thyroideum was found in seven larynges (Table 1). Of these, 6 were male larynges and one female larynx. In the female larynx, it was present unilaterally on the left oblique line of thyroid lamina. Of the six male larynges, three were present bilaterally and three were present unilaterally.

In the seven larynges, there were ten foramens. They were grouped in relation to oblique line. (Table 2).

\begin{tabular}{|c|c|c|c|}
\hline $\begin{array}{c}\text { Relation } \\
\text { to Oblique } \\
\text { Line }\end{array}$ & $\begin{array}{c}\text { Anterior to } \\
\text { Oblique } \\
\text { Line }\end{array}$ & $\begin{array}{c}\text { Posterior } \\
\text { to Oblique } \\
\text { Line }\end{array}$ & $\begin{array}{c}\text { In the } \\
\text { Oblique } \\
\text { Line }\end{array}$ \\
\hline $\begin{array}{c}\text { Number of } \\
\text { foramen }\end{array}$ & 3 & 3 & 4 \\
\hline \multicolumn{3}{|c|}{ Table 2: Foramen Thyroideum Relation with Oblique } \\
Line
\end{tabular}

All FT had neurovascular component as its content.

\begin{tabular}{|c|c|c|c|c|c|}
\hline$\stackrel{\Xi}{\Xi}$ & $\stackrel{\bar{\nu}}{\check{\nu}}$ & $\stackrel{\vec{E}}{\Xi}$ & 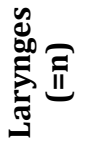 & 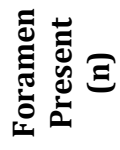 & $e^{\mathfrak{e}}$ \\
\hline Gruber(3) & 1876 & Germany & 170 & 71 & 48 \\
\hline Dilworth(4) & 1921 & UK & 23 & 4 & 17.3 \\
\hline Waldeyer(3) & 1927 & Germany & 100 & 55 & 55 \\
\hline Roncallo(3) & 1948 & Italy & 57 & 3 & 5.2 \\
\hline $\begin{array}{c}\text { Guerrier and } \\
\text { Prioton(3) }\end{array}$ & 1954 & France & 94 & 24 & 26 \\
\hline $\begin{array}{c}\text { Keen and } \\
\text { Wainwright }(3) \\
\end{array}$ & 1958 & $\begin{array}{l}\text { South } \\
\text { Africa }\end{array}$ & 133 & 23 & 17 \\
\hline Afifi (3) & 1970 & France & 16 & 7 & 44 \\
\hline
\end{tabular}

\begin{tabular}{|c|c|c|c|c|c|}
\hline $\begin{array}{c}\text { Jelisiejew and } \\
\text { Szmurlo(3) }\end{array}$ & 1972 & Poland & 484 & 184 & 38 \\
\hline Lang et al(3) & 1984 & Germany & 22 & 6 & 27 \\
\hline $\begin{array}{c}\text { Zemlin et al } \\
\text { (3) }\end{array}$ & 1984 & USA & 66 & 22 & 33 \\
\hline $\begin{array}{c}\text { Kirchner et } \\
\text { al(3) }\end{array}$ & 1989 & USA & 190 & 86 & 45 \\
\hline Leon et al (2) & 1997 & Spain & 90 & 28 & 31 \\
\hline He et al (3) & 1999 & France & 50 & 1 & 2 \\
\hline $\begin{array}{c}\text { Ortug C et } \\
\text { al(3) }\end{array}$ & 2004 & Turkey & 50 & 6 & 12 \\
\hline $\begin{array}{c}\text { Ramsaroop L } \\
\text { et al(5) }\end{array}$ & 2010 & $\begin{array}{c}\text { South } \\
\text { Africa }\end{array}$ & 80 & 6 & 7.5 \\
\hline Joshi et al (6) & 2011 & India & 50 & 5 & 10 \\
\hline \multicolumn{2}{|c|}{ Present study } & India & 60 & 7 & 11.6 \\
\hline \multicolumn{2}{|c|}{ Table 3: Comparison with Previous Studies } \\
\hline
\end{tabular}

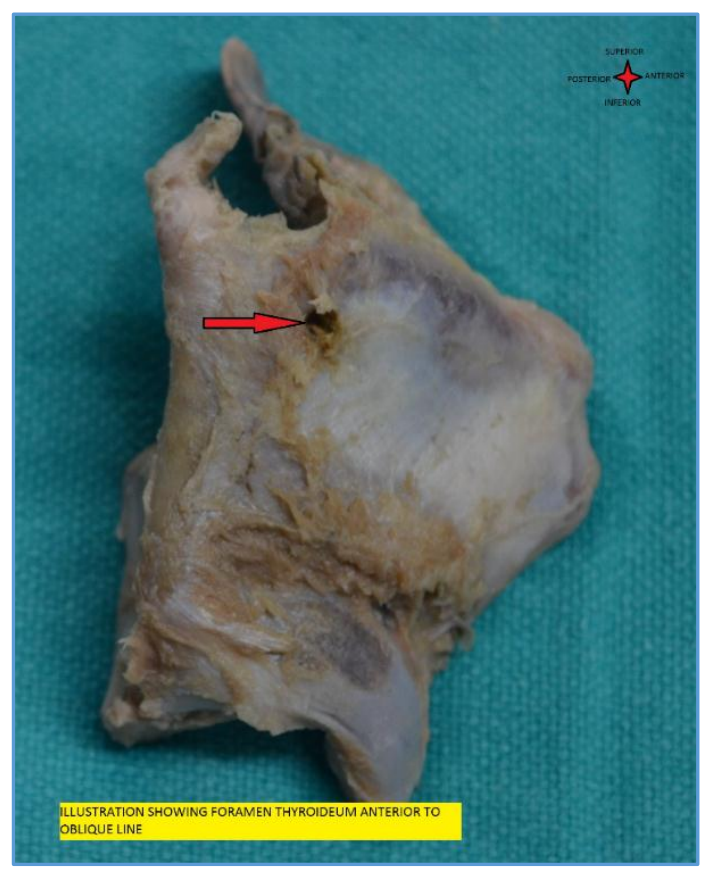

Anterior of Oblique Line

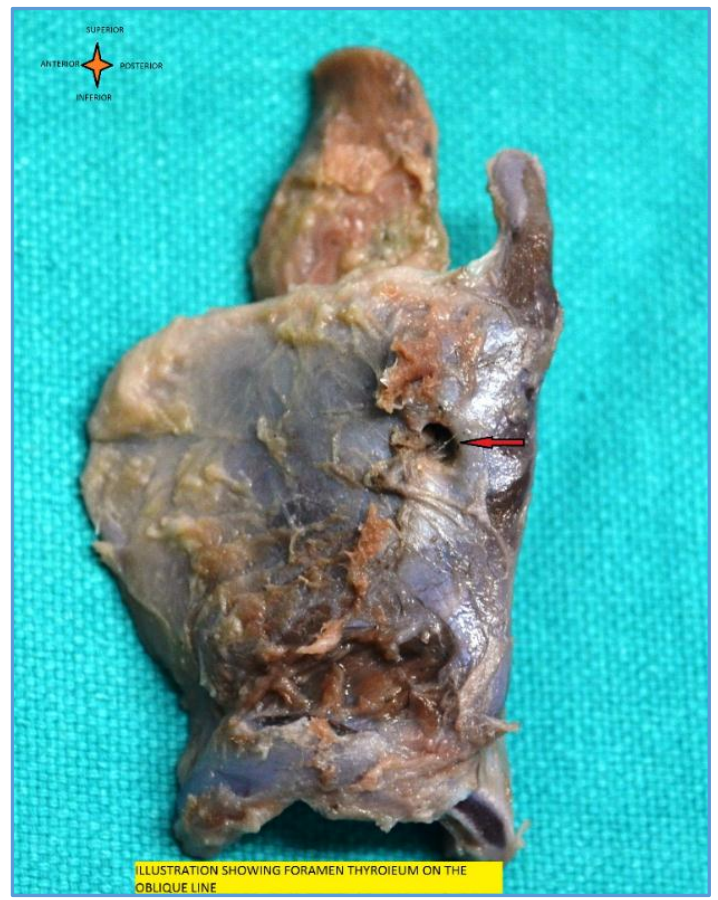

On the Oblique Line 


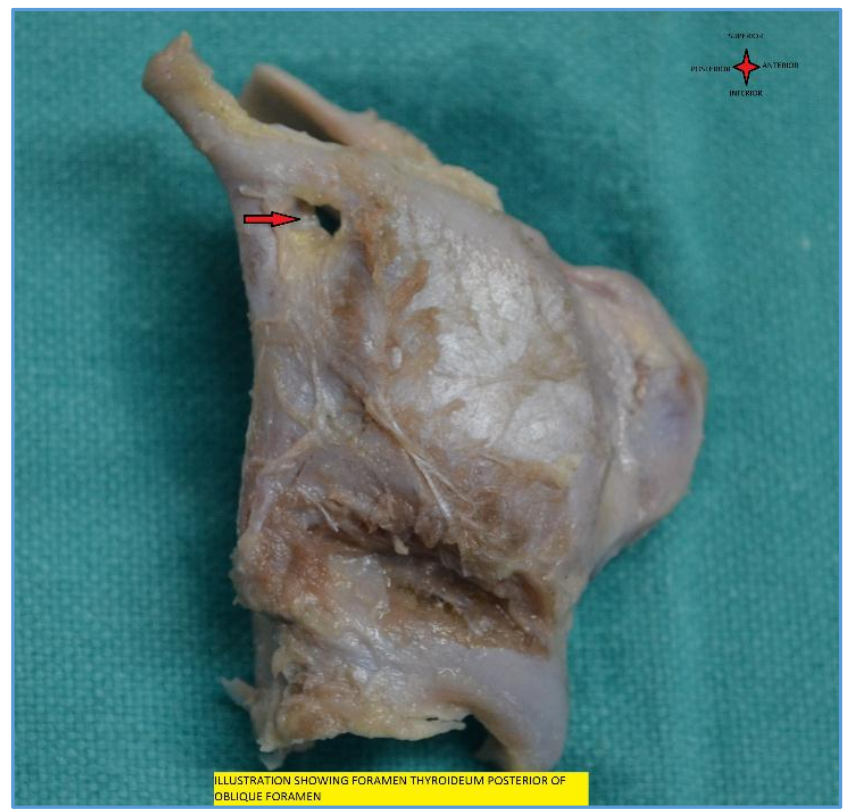

Posterior of Oblique Line

\section{DISCUSSION}

The incidence of the FT varies from $5-55 \%$ as seen in Table 3 . It is more in Europe and USA than in Indian population. We reviewed 1735 larynges including our own study. The combined incidence was found to be $31.00 \%$, which is quite greater than our finding of $11.00 \%$.

Leon et al reported in his study relation of foramen thyroideum to the oblique line, the foramen thyroideum (FT) was found in a variable position: below (28 cases), right at the upper end (four cases), and above the oblique line (nine cases).(2)

Ortug $\mathrm{C}$ et al reported six larynges having foramen thyroideum, one specimen had bilateral and five specimens had unilateral. Of the five unilateral, two in left and three in right and one specimen in left had double foramen. In relation to the oblique line, the foramen thyroideum was found in two positions, which were above (Six cases) and below (One case).

The author also reported foramen was located in the posterosuperior quadrant of the thyroid lamina beneath the superior tubercle except one double FT that extended down to the posteroinferior region. ${ }^{(3)}$

Joshi et al reported one on right side, three on left side, and one bilateral out of 50 cadavers in an Indian population. Foramen thyroideum were located on the oblique line in one specimen on right side. Foramina were located in three specimens on left side behind the oblique line and in one specimen it was present in front of the oblique line just below the superior thyroid tubercle.(6)

Dilworth reported presence of foramen thyroideum in four larynges out of 23. The external laryngeal nerve passes through three foramina out of four. This foramen was present twice on the left side, once on the right. In a fourth specimen, it was present on both sides and in this specimen it contained an artery. The foramen in this specimen was larger than in the other cases. The artery was apparently that branch of the superior thyroid, which is stated to accompany the internal laryngeal nerve, but which really enters the larynx through the thyrohyoid membrane on a lower plane quite close to the thyroid cartilage. When the nerve passed through the foramen, it joined the internal laryngeal nerve.(4)
Ramsaroop L et al (2010) reported six of the 80 (7.5\%) specimens examined had distinctly identifiable foramina. Five of the six cases ( 4 male, 1 female) displayed bilateral foramina (6.3\%), with one case ( 1 female) of a unilateral foramen $(1.3 \%)$. Of the larynges that had bilateral foramina, a single case presented with two foramina on the same (right) thyroid lamina.(5)

Raikos A et al (2013) in their review on foramen thyroideum reported the overall frequency was $28.3 \%$ in adults, $15 \%$ in children and neonates, $40.6 \%$ in embryos and foetuses. The content of the thyroid foramina was a neurovascular bundle in $41.2 \%$ of studies. An equal number of studies define a nerve as the common content while only in $17.6 \%$ the usual content was a vessel. Interestingly, in $11.8 \%$, the content was just connective tissue or a pit.(7)

In the present study, foramen thyroideum was found in seven larynges. In the seven larynges, there were ten foramens. They were grouped in relation to oblique line. Three foramens were present anterior, three posterior, and four in the oblique line.

The variant is of high interest for surgeons intervening in the larynx due to potential complications such as local bleeding and unwanted neural impairment. The oblique line of the thyroid lamina acts as the best topographical landmark to identify any aberrant anatomy related to a thyroid foramen.(7)

\section{CONCLUSION}

Foramen thyroideum is present in significant number of cases (11\%), so it requires further studies in different part of Indian population to establish its incidence as a whole. It cannot be neglected due to surgical and other clinical significance.

\section{ACKNOWLEDGEMENT}

We want to acknowledge Dr. Pritha S Bhuiya (Professor and HOD GSMC, Mumbai), Dr. L Rajgopal (Additional Professor, GSMC, Mumbai), Dr. K Shyam Kishore (Additional Professor, GSMC, Mumbai), Dr. P Iyer (Associate Professor, GSMC, Mumbai), and all staff members of Department of Anatomy of Seth G.S. Medical College, Mumbai, for their cooperation and suggestion in doing this research work.

\section{REFERENCES}

1. Standring S, Anatomy G. The anatomical basis of clinical practice. $40^{\text {th }}$ ed. Philadelphia: London, Churchill Livingstone 2008:577-80.

2. Leon X, Maranillo E, Mirapeix RM, et al. Foramen thyroideum: a comparative study in embryos, foetuses, and adults. Laryngoscope 1997;107(8):1146-50.

3. Ortug C, Gunduz T, Sam B. The incidence of the foramen thyroideum in Turkish population. Surgical and Radiologic Anatomy: SRA 2005;27(6):491-4.

4. Dilworth TFM. The nerves of the human larynx. Journal of Anatomy 1921;56(Pt 1):48-52.

5. Ramsaroop L, Hurrinarain K, Partab P, et al. The incidence of the foramen thyroideum in the South African population. Int J Morphol 2010;28(2):433-8.

6. Joshi MM, Joshi SS, Joshi SD. The presence of the foramen thyroideum: a cadaveric study in western region of the India. Calicut Med J 2011;9(2):e3.

7. Raikos A, Paraskevas GK. The thyroid foramen. Clinical Anatomy 2013;26(6):700-8. 